\title{
Pengembangan Perangkat Pembelajaran Matematika Dengan Kombinasi Pendekatan Matematika Realistik Dan Scientific Pada Siswa Kelas VII SMP
}

\author{
Sirajuddin \\ Pendidikan Matematika, Universitas Muhammadiyah Mataram, sirajuddin.ekhy@yahoo.com
}

INFO ARTIKEL
Riwayat Artikel:
Diterima: 03-09-2017
Disetujui: 17-10-2017

Kata Kunci:
$\begin{aligned} & \text { Developing Mathematics } \\ & \text { Learning, Realistic and } \\ & \text { Scientific } \\ & \text { Approache Mixed }\end{aligned}$

\begin{abstract}
ABSTRAK
Abstrak: Penelitian ini merupakan penelitian pengembangan (developmental research). Untuk mengembangkan perangkat pembelajaran yang valid, praktis, dan efektif. Perangkat pembelajaran yang dimaksud dalam penelitian ini yaitu: Rencana Pelaksanaan Pembelajaran (RPP), Lembar Kegiatan Siswa (LKS), Buku teks pelajaran, dan Tes Hasil Belajar (THB). Proses pengembangan perangkat pembelajaran menggunakan model 4-D dari Thiagarajan yang terdiri dari 4 tahapan yaitu: (1) tahap pendefinisian, (2) tahap perancangan, (3) tahap pengembangan, (4) tahap penyebaran. Perangkat pembelajaran yang dikembangkan divalidasi oleh dua orang ahli dengan nilai rata-rata keseluruhan dari tiap aspek perangkat pembelajaran himpunan dengan kombinasi pendekatan realistik dan saintifik yang dihasilkan (buku teks pelajaran, rencana pelaksanaan pembelajaran, lembar kegiatan siswa dan tes hasil belajar) dinyatakan valid dan layak untuk diujicobakan. Uji coba dilakukan pada Kelas VIISMP N 21 Mataram dengan jumlah siswa sebanyak 29 orang. Dari hasil analisis keterlaksanaan perangkat menunjukkan bahwa keterlaksanaan perangkat pembelajaran himpunan berbasis kombinasi realistik dan saintifik memenuhi kriteria praktis dan berada pada kategori sangat baik. Serta memenuhi kriteria efektif yaitu diperoleh respon siswa positif terhadap pembelajaran, aktifitas siswa berada pada kategori sangat aktif dan hasil belajar telah tuntas secara klasikal (84,7\% siswa yang memperoleh nilai di atas 75 dari nilai ideal 100). Dengan demikian, perangkat pembelajaran himpunan dengan kombinasi pendekatan realistik dan saintifik telah valid, praktis dan efektif.
\end{abstract}

\begin{abstract}
This studi was develomental research to develop learning package which is valid, practical, and effective. The intended learning package in this study is as follows: lesson plan, student's workbook, textbook, and test of learning result. The development process of learning package employed 4-D model based on thiagarajan which consist of 4 phases, namely (1) defining phase, (2) design phase, (3) development phase, and (4) dissemination phase. The learning package developed was validated by two experts with the overall aspect of each aspect of the set learning with combination of realistic and scientific approaches produced (textbook, lesson plan, student's workbook, and test of learning result) is confirmed as valid and feasible to be tested. The test is conducted to grade VII at SMP N 21 Mataram with the total of 29 students. The result base on the analysis of package implementation reveals that the set of learning sets based on reaistic and scientific approach meets effective criteria wich is obtained from positive response of the students toward learning; students' activities is in very active category and the learning result has completed calssically (84.7\% students obtain the score above 75 from the ideal 100). Therefore, the set learning package with realistic and scientific mixed approaches is valid, practical, and effective.
\end{abstract}

\section{A. LATAR BELAKANG}

Pendidikan dapat diartikan dari berbagai sudut pandang, misalnya pendidikan berwujud sebagai suatu sistem, artinya pendidikan dipandang sebagai keseluruhan gagasan terpadu yang mengatur usahausaha sadar untuk membina seseorang mencapai harkat kemanusiaannya secara utuh; pendidikan berwujud sebagai suatu proses, artinya pendidikan dipandang sebagai pelaksana usaha-usaha untuk mencapai tujuan tertentu dalam rangka mencapai harkat kemanusiaan seseorang secara utuh; dan pendidikan berwujud sebagai suatu hasil, artinya pendidikan dipandang sebagai sesuatu yang telah dicapai atau dimiliki seseorang setelah proses pendidikan berlangsung. 
Pembelajaran yang selama ini mendominasi kelas-kelas matematika di Indonesia umumnya berbasis pada behaviorisme dengan penekanan pada transfer pengetahuan dan latihan (Ratumanan, 2004). Guru mendominasi kelas dan berfungsi sebagai sumber belajar utama, dalam arti guru mengajari siswa. Guru menyajikan pengetahuan matematika kepada siswa, siswa memperhatikan penjelasan dan contoh yang diberikan oleh guru, kemudian siswa menyelesaikan soal-soal sejenis yang diberikan guru. Pembelajaran semacam ini kurang memperhatikan aktivitas aktif siswa, interaksi siswa, dan konstruksi pengetahuan oleh siswa. Aktivitas aktif siswa yang dimaksudkan di sini tidak hanya sekedar menyelesaikan soal-soal sesuai contoh yang diberikan guru, tetapi perlu pula melibatkan berbagai aktivitas aktif yang dapat merangsang kemampuan berpikir dan kemampuan memecahkan masalah yang merupakan tujuan dari pembelajaran matematika.

Berdasarkan uraian di atas, pembelajaran matematika di kelas seyogyanya ditekankan pada keterkaitan antara konsep-konsep matematika dengan pengalaman anak sehari-hari. Selain itu, perlu menerapkan kembali konsep matematika yang telah dimiliki anak pada kehidupan sehari-hari atau pada bidang lain. Salah satu pembelajaran matematika yang berorientasi pada matematisasi pengalaman sehari-hari (mathematize of everyday experience) adalah pembelajaran matematika realistik (PMR).

Pada proses pembelajaran dengan PMR, siswa menjadi fokus dari semua aktivitas dalam proses belajar mengajar di kelas. Hal ini menjadikan siswa aktif dalam kegiatan belajar mengajar. Pengalaman belajar yang diperoleh siswa melalui kegiatan bertindak, mencari dan menemukan sendiri tidak mudah dilupakan. Untuk itu guru mengajar tidak hanya sekedar memberikan ilmu pengetahuan, tetapi menciptakan situasi yang menggiring siswa untuk berani bertanya, berani mengemukakan pendapat, menghargai pendapat temannya, serta menemukan sendiri fakta atau konsep yang dipelajari. Dengan demikian, pendekatan PMR dapat memberikan pengalaman kepada anak untuk menemukan kembali atau jika mungkin menemukan hal-hal baru dengan menggunakan pengetahuan, keterampilan, dan penalaran yang telah dimiliki sebelumnya. Oleh karena itu, kreativitas guru amat penting dalam merancang pembelajaran dengan pendekatan PMR sesuai dengan lingkungannya masing-masing.

Pendekatan realistik dalam penerapannya dalam pembelajaran matematika juga membutuhkan perangkat pembelajaran yang sesuai dengan pendekatan tersebut. Di sisi lain pembelajaran matematika realistik merupakan pendekatan pembelajaran yang masih relatif baru di Indonesia umumnya dan di Mataram khususnya sehingga perangkat pembelajaran yang dapat mendukung pelaksanaannya di kelas masih sangat terbatas. Hal ini mendorong peneliti untuk mengembangkan perangkat pembelajaran dengan pendekatan matematika realistik materi himpunan di Kelas VII SMPN 21 Mataram.

\section{B. METODE PENELITIAN}

\section{Jenis Penelitian}

Sesuai judul penelitian, maka penelitian yang dilakukan adalah jenis penelitian pengembangan (Research and Development) yang akan mengembangkan perangkat pembelajaran materi himpunan dengan pendekatan realistik dan scientific. Model pengembangan yang digunakan adalah model 4-D dari Thiagarajan, Semmel dan Semmel (1974). Perangkat pembelajaran yang dikembangkan adalah Rencana Pelaksanaan Pembelajaran (RPP), Buku Siswa (BS), Lembar Kegiatan Siswa (LKS), dan Tes Hasil Belajar (THB).

\section{Subjek Penelitian}

Subjek penelitian ini adalah siswa Kelas VII A SMP N 21 Mataram semester ganjil tahun pelajaran 2016/2017.

\section{Prosedur Pengembangan Perangkat Pembelajaran}

Perangkat pembelajaran yang dikembangkan adalah perangkat pembelajaran matematika dengan kombinasi pendekatan realistik dan saintifik. Pengembangan perangkat pembelajaran menggunakan model Thiagarajan, Semmel dan Semmel yang dikenal dengan 4-D yaitu pendefinisian (define), perancangan (design), pengembangan (develop), dan penyebaran (disseminate).

Selanjutnya tahap-tahap model pengembangan perangkat pembelajaran yang dikemukakan oleh Thiagarajan dkk, diuraikan sebagai berikut:

\section{a. Tahap pendefinisian (define)}

Tujuan dari tahap ini adalah untuk menetapkan dan menentukan syarat-syarat pembelajaran yang meliputi tujuan pembelajaran dan batasan materi pembelajaran. Adapun langkah-langkah pada tahap ini adalah sebagai berikut:

1) Analisis awal-akhir

Berdasarkan hasil diskusi dengan guru matematika di SMP N 21 Mataram tentang kegiatan pembelajaran matematika di sekolah tersebut, diperoleh informasi bahwa masalah mendasar yang perlu diupayakan pemecahannya adalah cara penyajian bahan pelajaran. Kecenderungan pembelajaran selama ini kurang memberikan kesempatan yang cukup kepada siswa untuk mengembangkan kemampuannya sendiri 
2) Analisis siswa

Analisis siswa dilakukan untuk menelaah tentang karakteristik siswa.Karakteristik siswa yang dimaksud meliputi latar belakang pengetahuan siswa, bahasa yang digunakan dan perkembangan kognitif siswa.Hasil telaah tersebut digunakan sebagai bahan pertimbangan untuk mengembangkan perangkat pembelajaran matematika dengan pendekatan realistik dan saintifik.

3) Analisis materi

Kegiatan yang dilakukan pada langkah ini adalah mengidentifikasi, merinci, dan menyusun secara sistematis materi-materi utama yang akan dipelajari siswa, selanjutnya materi tersebut disusun secara hirarkis. Materi pelajaran yang digunakan dalam penelitian ini adalah materi himpunan pada Kelas VII SMP N 21 Mataram semester ganjil.

4) Analisis tugas

Analisis tugas dilakukan setelah mengetahui materi yang akan diajarkan sehingga dapat diketahui tugas-tugas yang harus diselesaikan siswa selama pembelajaran dilaksanakan. Analisis tugas juga dapat memudahkan guru untuk merumuskan tujuan-tujuan khusus yang akan dicapai.

5) Spesifikasi tujuan pembelajaran

Dari analisis materi dan analisis tugas yang telah dilakukan, diharapkan dapat dihasilkan tujuan pembelajaran khusus yang merupakan dasar untuk menyusun tes dan merancang perangkat pembelajaran materi Himpunan .Kegiatan yang dilakukan pada langkah ini adalah merumuskan tujuantujuan pembelajaran khusus (indikator pencapaian) berdasarkan analisis materi dan analisis tugas. Perincian tujuan pembelajaran khusus tersebut merupakan dasar dalam penyusunan rancangan perangkat pembelajaran materi perbandingan dan skala

\section{b. Tahap perancangan (design)}

Tahap ini bertujuan untuk merancang perangkat pembelajaran dan instrumen penelitian sehingga diperoleh prototipe (perangkat pembelajaran dan instrumen penelitian contoh). Kegiatan yang dilaksanakan pada tahap ini terdiri atas empat kegiatan, yaitu: (1) pemilihan media, (2) pemilihan format dan (3) perancangan awal perangkat pembelajaran. Secara singkat masing-masing kegiatan pada tahap ini dijelaskan sebagai berikut:

1) Pemilihan media

Kegiatan ini dilakukan untuk menentukan media dan alat pembelajaran yang tepat untuk digunakan dalam pelaksanaan pembelajaran. Proses pemilihan media ini disesuaikan dengan hasil analisis tugas, analisis materi dan analisis siswa. Selain itu, media yang dipilih harus disesuaikan dengan karakteristik siswa dan fasilitas yang tersedia atau yang dapat disediakan di sekolah.

2) Pemilihan format

Kegiatan pada tahap ini meliputi pemilihan format untuk mendesain atau merancang isi pembelajaran, pemilihan strategi, pendekatan, metode pembelajaran dan sumber belajar.

3) Perancangan awal

Kegiatan yang dilaksanakan dalam perancangan awal adalah penulisan perangkat pembelajaran, yang meliputi: (1) Rencana Pelaksanaan Pembelajaran, (2) Buku Siswa, (3) Lembar Kegiatan Siswa, (4) Tes Hasil Belajar. Semua perangkat yang dihasilkan pada tahap ini disebut draft awal.

\section{c. Tahap pengembangan (develop)}

Tujuan dari tahap ini adalah untuk menghasilkan draf perangkat pembelajaran yang telah direvisi berdasarkan masukan para ahli dan data yang diperoleh dari hasil uji keterbacaan dan data hasil ujicoba. Secara singkat masing-masing kegiatan pada tahap ini dijelaskan sebagai berikut:

1) Penilaian ahli

Setelah semua perangkat pembelajaran draft awal selesai ditulis pada tahap perancangan, selanjutnya dilakukan penilaian (divalidasi) oleh ahli. Yang dimaksud ahli dalam hal ini adalah para validator yang berkompeten untuk melakukan penilaian terhadap perangkat pembelajaran. Saran dari para validator digunakan sebagai bahan untuk melakukan revisi perangkat hasil pengembangan yang dilakukan pada tahap perancangan (draft awal). Secara umum validasi ahli mencakup:

2) Uji coba

Perangkat pembelajaran yang telah direvisi tersebut selanjutnya untuk diujucobakan. Ujicoba hanya dilakukan pada satu kelas saja. Tujuan pelaksanaan uji coba perangkat (buku siswa, rencana pelaksanaan pembelajaran, LKS dan tes hasil belajar. Dalam uji coba perangkat pembelajaran ini, semua data berupa: respons, komentar dan saran dari siswa dan pengamat serta beberapa kejadian penting selama pelaksanaan uji coba dicatat kemudian dianalisis sebagai masukan untuk melakukan revisi perangkat pembelajaran.

\section{d. Tahap penyebaran (disseminate)}

Tahap ini merupakan tahap penggunaan perangkat yang telah dikembangkan pada skala yang lebih luas, tetapi dalam penelitian ini hanya 
sebatas sosialisasi atau penyebaran perangkat pembelajaran untuk memperoleh masukan atau saran-saran yang dijadikan sebagai bahan pertimbangan dalam merevisi perangkat pembelajaran yang telah dikembangkan.Hasil revisi pada tahap ini menghasilkan draft final perangkat pembelajaran.

\section{e. Instrumen Penelitian}

Instrumen-instrumen dalam penelitian ini adalah: (1) lembar validasi perangkat pembelajaran, (2) lembar observasi, (3) angket respons siswa, dan (4) tes penguasaan siswa terhadap materi pelajaran. Uraian dari keempat instrumen yang dikembangkan sebagai berikut:

\section{f. Lembar validasi perangkat pembelajaran}

Lembar validasi perangkat pembelajaran digunakan untuk memperoleh informasi tentang kualitas perangkat pembelajaran berdasarkan penilaian para ahli.Informasi yang diperoleh melalui instrumen ini digunakan sebagai masukan dalam merevisi semua perangkat pembelajaran yang telah dikembangkan. Pada lembar validasi perangkat pembelajaran, validator menuliskan penilaian terhadap masing-masing perangkat yang terdiri dari: Rencana Pelaksanaan Pembelajaran (RPP), Buku Siswa (BS), dan Lembar Kegiatan Siswa (LKS).

Penilaian terdiri dari 4 kategori, yaitu tidak baik (nilai 1), kurang baik (nilai 2), baik (nilai 3), dan sangat baik (nilai 4).

\section{g. Lembar Observasi}

Ada tiga macam lembar observasi, yaitu: (1) lembar observasi aktivitas siswa, (2) lembar observasi pengelolaan pembelajaran, dan (3) lembar observasi keterlaksanaan perangkat pembelajaran. Ketiga lembar observasi tersebut dijelaskan sebagai berikut:

1) Lembar observasi aktivitas siswa

Instrumen ini digunakan untuk memperoleh data tentang aktivitas siswa selama proses pembelajaran dengan menggunakan perangkat pembelajaran matematika dengan kombinasi pendekatan mateematika realistik dan dan saintifik. Informasi yang diperoleh melalui instrumen ini digunakan sebagai bahan pertimbangan untuk merevisi Rencana Pelaksanaan Pembelajaran (RPP), Buku teks pelajaran, dan Lembar Kegiatan Siswa (LKS) . Pada lembar observasi aktivitas siswa pengamat melihat aktifitas siswa yang sesuai dengan aspekaspek pada langkah-langkah yang telah ditetapkan.

2) Lembar observasi pengelolaan pembelajaran

Instrumen ini digunakan untuk memperoleh data tentang kemampuan guru dalam mengelola pembelajaran dengan menggunakan perangkat pembelajaran dengan kombinasi pendekatan mateematika realistik dan dan saintifik.. Data kemampuan guru mengelola pembelajaran diperoleh melalui pengamatan yang dilakukan oleh seorang pengamat dengan cara memberi tanda cek $(\sqrt{ })$ pada kolom yang sesuai dengan kategori pengamatan yang diamati. Kriteria penilaian pengelolaan pembelajaran terdiri dari 4 kriteria penilaian, yaitu: 1 = tidak baik, 2 = kurang baik, 3 = baik, 4 = sangat baik.

3) Lembar Observasi keterlaksanaan perangkat pembelajaran

Lembar observasi keterlaksanaan perangkat digunakan untuk memperoleh data lapangan tentang kepraktisan perangkat pembelajaran yang dikembangkan. Data diperoleh melalui pengamat (observer) yang mengadakan pengamatan terhadap guru yang melaksanakan pembelajaran di kelas. Data tentang keterlaksanaan perangkat pembelajaran diperoleh dengan memberikan lembar observasi kepada observer untuk digunakan dalam mengamati keterlaksanaan aspek-aspek atau komponen-komponen perangkat pembelajaran pada saat guru melaksanakan pembelajaran di kelas sesuai petunjuk yang diberikan.

\section{h. Respons siswa terhadap kegiatan pembelajaran}

Angket digunakan untuk mengumpulkan informasi tentang respons siswa terhadap kegiatan pembelajaran dan perangkat pembelajaran dengan pendekatan pembelajaran matematika realistik. Siswa memberikan tanda cek $(\sqrt{ })$ pada kolom yang tersedia untuk setiap pertanyaan yang diajukan. Angket tersebut diberikan kepada siswa pada akhir kegiatan pembelajaran.

\section{i. Tes hasil belajar}

Untuk mengetahui tingkat penguasaan siswa terhadap materi yang telah diajarkan, dikembangkan tes hasil belajar berdasarkan tujuan pembelajaran yang akan dicapai. Tes tersebut diberikan ke siswa setelah proses pembelajaran materi himpunan selesai. Penskoran tes hasil belajar siswa menggunakan skala bebas yang tergantung dari tingkat kesukaran dan cakupan butir soal tersebut.

\section{Teknik Analisis Data}

\section{a. Analisis data kevalidan}

Data hasil validasi para ahli untuk masingmasing perangkat pembelajaran dianalisis. Adapun kegiatan yang dilakukan dalam proses analisis data kevalidan perangkat pembelajaran adalah sebagai berikut: 
1) Melakukan rekapitulasi hasil penilaian ahli ke dalam tabel yang meliputi: (a) aspek $\left(\mathrm{A}_{\mathrm{i}}\right)$, (b) kriteria $\left(\mathrm{K}_{\mathrm{i}}\right)$, (c) hasil penilaian validator $\left(\mathrm{V}_{\mathrm{ji}}\right)$;

2) Mencari rerata hasil penilaian ahli untuk setiap kriteria dengan rumus: $\overline{K_{i}}=\frac{\sum_{j=1}^{n} V_{i j}}{n}$, dengan:

$\overline{K_{i}}=$ rerata kriteria ke-i

$V_{j i}=$ skor hasil penilaian terhadap kriteria

ke-i oleh penilai ke-j

$n=$ banyaknya penilai

3) Mencari rerata tiap aspek dengan rumus:

$\overline{A_{i}}=\frac{\sum_{j=1}^{n} \bar{K}_{i j}}{n}$, dengan:

$\overline{A_{i}}=$ rerata aspek ke-i

$\bar{K}_{j i}=$ rerata untuk aspek ke-i kriteria ke-j

$n$ = banyaknya kriteria dalam aspek ke-i

4) Mencari rerata total ( $\bar{X}$ ) dengan rumus:

$\bar{X}=\frac{\sum_{i=1}^{n} \bar{A}_{i}}{n}$, dengan :

$\bar{X}=$ rerata total

$\overline{A_{i}}=$ rerata aspek ke-i

$n=$ banyaknya aspek

5) Menentukan kategori validitas setiap kriteria $\overline{K_{i}}$ atau rerata aspek $\overline{A_{i}}$ atau rerata total $\bar{X}$ dengan kategori validasi yang telah ditetapkan;

6) Kategori validitas Nurdin (2007:143) sebagai berikut:

$$
\begin{array}{ll}
3,5 \leq M \leq 4 & \text { sangat valid } \\
2,5 \leq M<3,5 & \text { valid } \\
1,5 \leq M<2,5 & \text { cukup valid } \\
M<1,5 & \text { tidak valid }
\end{array}
$$

$M=\overline{K_{i}}$ untuk mencari validitas setiap

kriteria

$M=\overline{A_{i}}$ untuk mencari validitas setiap aspek. $M=\bar{X}$ untuk mencari validitas keseluruhan aspek

Kriteria yang digunakan untuk menyatakan perangkat pembelajaran memiliki derajat validitas yang memadai adalah nilai rata-rata validitas untuk keseluruhan aspek minimal berada pada kategori cukup valid dan nilai validitas untuk setiap aspek minimal berada dalam kategori valid. Jika tidak memenuhi kriteria tersebut, maka perlu dilakukan revisi berdasarkan saran dari para validator atau dengan melihat kembali aspek-aspek yang nilainya kurang.

\section{b. Analisis pembelajaran}

Analisis terhadap keefektifan perangkat pembelajaran dengan kombinasi pendekatan mateematika realistik dan dan saintifik.yang meliputi: (1) hasil belajar siswa, (2) aktivitas siswa, (3) respons siswa, oleh karena itu, kegiatan analisis data terhadap komponen itu adalah sebagai berikut:

\section{Hasil belajar siswa}

Analisis terhadap hasil belajar dilakukan dengan membagi skor perolehan siswa dengan skor maksimum yang ditentukan kemudian dikalikan dengan seratus.Kriteria yang digunakan untuk menentukan kategori hasil belajar adalah skala yang ditentukan oleh Depdiknas (2006).

1) Kemampuan $85 \%-100 \%$ dikategorikan sangat tinggi.

2) Kemampuan 65\% - 84\% dikategorikan tinggi.

3) Kemampuan $55 \%$ - $64 \%$ dikategorikan sedang.

4) Kemampuan $35 \% \quad-44 \%$ dikategorikan rendah.

5) Kemampuan 0\%-34\% dikategorikan sangat rendah.

Standar umum diatas bergantung terhadapa jumlah skor maksimal yang digunakan pada hasil belajar.Pada materi Himpunan Minimal dalam (SKKM) yang harus dipenuhi oleh seorang siswa adalah 75.Jika seorang siswa memperoleh $S \geq 75$ maka siswa yang bersangkutan mencapai ketuntasan individu.Jika minimal 85\% siswa mencapai skor minimal 75, maka ketuntasan klasikal telah tercapai (SKMM ditentukan oleh pihak sekolah bersangkutan).

\section{Data Respons Siswa}

Data respon siswa diperoleh melalui instrumen angket respons siswa, dianalisis dengan langkah-langkah berikut:

1) Menghitung banyak siswa yang memberi respon positif terhadap pertanyaan atau pernyataan dari setiap aspek, dengan kategori "negatif" yaitu kriteria 1 dan 2, dan kategori "positif" yaitu kriteria 3 dan 4, berikut kriteria yang diberikan:

$$
\begin{array}{ll}
1 & =\text { Sangat negatif } \\
2 & =\text { Negatif } \\
3 & =\text { Positif } \\
4 & =\text { Sangat positif }
\end{array}
$$

2) Menghitung persentase dari (1).

3) Menentukan kategori untuk respons positif siswa dengan cara mencocokkan hasil persentase dengan kriteria yang ditetapkan. 
Jika hasil analisis menunjukkan bahwa respons siswa belum positif, maka dilakukan revisi terhadap proses pembelajaran terkait dengan aspek-aspek yang nilainya kurang.

Kriteria yang ditetapkan untuk menyatakan bahwa para siswa memiliki respon positif adalah minimal 50\% dari siswa memberi respon positif terhadap minimal $70 \%$ dari jumlah item pertanyaan atau pernyataan yang ada pada setiap aspek.

\section{Aktivitas siswa}

Data hasil observasi aktivitas siswa dianalisis secara kualitatif, dalam hal ini menjelaskan atau memaparkan kegiatan yang dilakukan siswa selama proses pembelajaran berlangsung. Pengamatan dilakukan terhadap aktivitas siswa dalam mengikuti tiap-tiap aspek dari langkahlangkah kegiatan pembelajaran dengan kombinasi pendekatan mateematika realistik dan dan saintifik.. Dari hasil observer setiap pertemuan,ditentukan nilai rata-rata dari setiap aspek aktivitas siswa (AS) dari pertemuan pertama sampai pertemuan ketiga. Nilai AS ini selanjutnya dikonfirmasikan dengan interval penentuan kategori aktivitas siswa selama pembelajaran berlangsung (Nurhusain, 2012), yaitu:

1. $\overline{A S} \leq 1,5 \quad$ berarti TA (Tidak Aktif)

2. $1,5<\overline{A S} \leq 2,5 \quad$ berarti KA (KurangAktif)

3. $2,5<\overline{A S} \leq 3,5$ berarti CA (Cukup Aktif)

4. $3,5<\overline{A S} \leq 4$ berarti A (Aktif)

Kriteria yang digunakan untuk memutuskan bahwa aktivitas siswa selama dengan kombinasi pendekatan mateematika realistik dan dan saintifik. memadai adalah nilai AS minimal berada dalam kategori "aktif".

\section{c. Analisis data kepraktisan perangkat pembelajaran}

Analisis data keterlaksanaan perangkat pembelajaran dengan kombinasi pendekatan mateematika realistik dan dan saintifik yang dimaksud di sini adalah keterlaksanaan pengelolaan pembelajaran dengan kombinasi pendekatan mateematika realistik dan dan saintifik. Analisis dilakukan terhadap hasil penilaian dari satu observer yang mengamati kemampuan guru mengelola pembelajaran dengan kombinasi pendekatan mateematika realistik dan dan saintifik di dalam kelas. Dari hasil observer setiap pertemuan, ditentukan nilai rata-rata Kegiatan Guru (KG) dari pertemuan pertama sampai pertemuan ketiga. Nilai KG ini selanjutnya dikonfirmasikan dengan interval penentuan kategori kemampuan guru mengelola pembelajaran (Nurdin 2007), yaitu:
1. $\overline{K G} \leq 1,5$
berarti TB(Tidak Baik)
2. $1,5<\overline{K G} \leq 2,5$
berarti KB (Kurang Baik)
3. $2,5<\overline{K G} \leq 3,5$ berarti CB (Cukup Baik)
4. $3,5<\overline{K G} \leq 4 \quad$ berarti B (Baik)

\section{HASIL DAN PEMBAHASAN \\ 1. Deskripsi Hasil Pengembangan Perangkat}

Salah satu tujuan penelitian ini adalah untuk mengembangkan perangkat pembelajaran matematika dengan pendekatan realistik dan scientific pada siswa kelas VII SMP N 21 Mataram yang valid, praktis dan efektif. Untuk memenuhi tujuan tersebut, terlebih dahulu dilakukan penelitian pengembangan yang menggunakan model 4-D. Hasil pengembangan perangkat tersebut berupa: Buku Teks Pelajaran, Rencana Pelaksanaan Pembelajaran (RPP), Lembar Kegiatan Siswa (LKS) dan Tes hasil belajar (THB).

Prosedur pengembangan perangkat ini menggunakan model pengembangan dari Thiagarajan yang dikenal dengan model 4-D (four $D$ models) dengan tahapan pengembangan yang terdiri atas tahap pendefinisian, tahap perancangan, tahap pengembangan dan tahap penyebaran. Hasil pengembangan perangkat pembelajaran materi Himpunan dengan kombinasi pendekatan realistik dan scientif diuraikan sebagai berikut:

\section{Hasil Tahap Pendefinisian (Define)}

Kegiatan ini ditetapkan terlebih dahulu sebagai landasan untuk melangkah ke tahaptahap pengembangan selanjutnya. Hasil setiap kegiatan pada tahap pendefinisian sebagai berikut:

1) Hasil analisis ujung depan

2) Hasil analisis siswa

3) Hasil analisis materi

4) Hasil analisis tugas

5) Hasil analisis spesifikasi tujuan pembelajaran

\section{Hasil Tahap Perancangan(Design)}

Tahap ini bertujuan merancang prototipe perangkat pembelajaran. Hasil pada tahap perancangan (design) berupa lima buah perangkat pembelajaran yaitu Bahan Ajar, Rencana Pelaksanaan Pembelajaran (RPP), Lembar Kegiatan Siswa (LKS) dan Tes Hasil Belajar. Perangkat pembelajaran yang dihasilkan pada tahap perancangan (design) ini disebut draft awal. Hasil dari masing-masing kegiatan pada tahap perancangan diuraikan sebagai berikut. 
1) Penyusunan tes

2) Hasil pemilihan media

3) Hasil pemilihan format

Pemilihan format perangkat pembelajaran bertujuan untuk memilih format dalam menyusun atau merancang perangkat pembelajaran, pemilihan strategi, pendekatan, metode pembelajaran dan sumber belajar.Isi dari perangkat pembelajaran tersebut disusun sesuai dengan pembelajaran yang mengkombinasikan pendekatan realistik dan saintifik. Secara umum format perangkat pembelajaran diuraikan sebagai berikut:

1) Rencana Pelaksanaan Pembelajaran (RPP)

2) Buku Siswa (BS).

3) Lembar Kegiatan Siswa (LKS).

4) Tes hasil belajar

\section{Hasil Tahap Pengembangan (Develop)}

Tahap pengembangan adalah tahap lanjutan dari tahap pendefinisian dan tahap perancangan dan merupakan tahapan ketiga dari model 4-D..

a. Deskripsi penilaian ahli terhadap perangkat pembelajaran

Draf I yang dihasilkan di validasi oleh ahli. Validasi para ahli di fokuskan pada format, isi, ilustrasi dan bahasa yang mencakup semua perangkat pembelajaran yang dikembangkan. Hasil validasi ahli berupa koreksi, kritik dan saran, yang kemudian digunakan sebagai dasar untuk melakukan revisi dan penyempurnaan terhadap perangkat pembelajaran. Perangkat pembelajaran yang merupakan hasil revisi berdasarkan masukan dari para validator disebut dengan Draft 2 . Penilaian ahli terhadap RPP, LKS, Buku Siswa, dan Tes Hasil Belajar didasarkan pada: format, bahasa, isi dan ilustrasi yang tertuang dalam instrumen lembar validasi perangkat pembelajaran.

Data hasil penilaian ahli terhadap RPP, LKS, Buku Siswa dan Tes Hasil Belajar, dapat dituliskan seperti pada tabel berikut.

TABEL 1

DESKRIPSI HASIL PENILAIAN AHLI TERHADAP PERANGKAT PEMBELAJARAN.

\begin{tabular}{clll}
\hline $\begin{array}{l}\text { Perang } \\
\text { kat }\end{array}$ & \multicolumn{1}{c}{ Indikator } & $\begin{array}{c}\text { Penil } \\
\text { aia } \\
\mathrm{n}\end{array}$ & Keterangan \\
\hline RPP & 1. $\begin{array}{l}\text { Kompetensi } \\
\text { Dasar }\end{array}$ & $\begin{array}{l}4,0 \\
\text { Indikator }\end{array}$ & $\begin{array}{c}\text { Sangat } \\
\text { Valid }\end{array}$ \\
& $\begin{array}{l}\text { 2. } \\
\text { Pencapaian KD }\end{array}$ & 3,5 & Sangat \\
& 3. Isi dan Kegiatan & 0 & Valid \\
& $\begin{array}{l}\text { Pembelajaran } \\
\text { 4. Bahasa }\end{array}$ & 2,8 & Valid \\
& 5. Waktu & 7 & \\
6. Penutup & & \\
\hline
\end{tabular}

\begin{tabular}{|c|c|c|c|}
\hline & & $\begin{array}{l}3,8 \\
3 \\
3,5 \\
0 \\
4,0 \\
0\end{array}$ & $\begin{array}{c}\text { Sangat } \\
\text { Valid } \\
\text { Sangat } \\
\text { Valid } \\
\text { Sangat } \\
\text { Valid }\end{array}$ \\
\hline & Rata-rata & $\begin{array}{l}3,6 \\
1\end{array}$ & $\begin{array}{c}\text { Sangat } \\
\text { Valid }\end{array}$ \\
\hline BS & $\begin{array}{l}\text { 1. Format } \\
\text { 2. Bahasa } \\
\text { 3. Ilustrasi } \\
\text { 4. Isi }\end{array}$ & $\begin{array}{l}3,0 \\
8 \\
3,5 \\
0 \\
3,0 \\
0 \\
3,2 \\
5\end{array}$ & $\begin{array}{c}\text { Valid } \\
\text { Sangat } \\
\text { Valid } \\
\text { Valid } \\
\text { Valid }\end{array}$ \\
\hline & Rata-rata & $\begin{array}{l}3,2 \\
0 \\
\end{array}$ & Valid \\
\hline LKS & $\begin{array}{l}\text { 1. Format } \\
\text { 2. Bahasa } \\
\text { 3. Isi }\end{array}$ & $\begin{array}{l}3,6 \\
6 \\
3,3 \\
3 \\
2,5 \\
0\end{array}$ & $\begin{array}{c}\text { Sangat } \\
\text { Valid } \\
\text { Valid } \\
\text { Kurang } \\
\text { Valid }\end{array}$ \\
\hline & Rata-rata & $\begin{array}{l}3,1 \\
6\end{array}$ & Valid \\
\hline HB & $\begin{array}{l}\text { 1. Validasi Isi } \\
\text { 2. Bahasa }\end{array}$ & $\begin{array}{l}3,3 \\
3 \\
3,3 \\
3\end{array}$ & $\begin{array}{l}\text { Valid } \\
\text { Valid }\end{array}$ \\
\hline & Rata-rata & $\begin{array}{l}3,3 \\
3\end{array}$ & Valid \\
\hline
\end{tabular}

Tabel di atas menunjukkan bahwa RPP, LKS, BS dan THB ditinjau dari indikator-indikatornya berada pada kategori valid dan sangat valid, selain itu semua validator memberikan kesimpulan bahwa perangkat yang telah dikembangkan adalah baik dan dapat digunakan dengan sedikit revisi.

Secara umum, hasil penilaian para ahli terhadap perangkat pembelajaran yang meliputi RPP, Buku Siswa, LKS dan THB dapat di lihat pada tabel berikut:

TABEL 2

RANGKUMAN HASIL VALIDASI PERANGKAT PEMBELAJARAN

\begin{tabular}{lcc}
\hline \multicolumn{1}{c}{ Sumber } & $\begin{array}{c}\text { Skor } \\
\text { Rata- } \\
\text { rata }\end{array}$ & Kriteria \\
\hline $\begin{array}{l}\text { Rencana pelaksanaan } \\
\text { pembelajaran }\end{array}$ & 3,61 & $\begin{array}{c}\text { Sangat } \\
\text { valid }\end{array}$ \\
\hline Buku siswa & 3,20 & Valid \\
\hline Lembar kegiatan siswa & 3,13 & Valid \\
\hline Tes hasil belajar & 3,33 & Valid \\
\hline
\end{tabular}

Berikut ini adalah gambaran data yang diperoleh dari hasil ujicoba berupa data aktifitas siswa, data 
keterlaksanaan perangkat pembelajaran, data tes hasil belajar dan data respons siswa.

\section{1) Analisis kepraktisan (keterlaksanaan) perangkat pembelajaran}

TABEL 3

HASIL PENGAMATAN PENGELOLAAN PEMBELAJARAN.

\begin{tabular}{llcl}
\hline No & \multicolumn{1}{c}{ Aspek yang diamati } & $\begin{array}{c}\text { Rata } \\
- \\
\text { Rata }\end{array}$ & Ket \\
\hline 1. & $\begin{array}{l}\text { Kegiatan Pendahuluan: } \\
\text { a. } \quad \begin{array}{l}\text { Memberikan apersepsi } \\
\text { tentang materi pembelajaran } \\
\text { yang lalu dan memotivasi } \\
\text { siswa. }\end{array}\end{array}$ & 4,00 & $\begin{array}{l}\text { Sanga } \\
\text { t baik }\end{array}$ \\
& bemperlihatkan gambar & 2,66 & $\begin{array}{l}\text { Kuran } \\
\text { g baik }\end{array}$ \\
& & & \\
& kepada siswa & &
\end{tabular}

2. Kegiatan Inti:

a. memancing pertanyaan kepada siswa terkait dengan apa yang mereka lakukan sehingga mereka dengan sadar mengetahui materi apa yang sedang dipelajari pada saat itu.

b. Guru menyajikan kerangka isi materi pembelajaran dan menunjukkan materi yang akan dibahas pada buku siswa

c. Guru mengarahkan siswa untuk melakukan analsis terhadap

fakta/kalimat/prosedur.

d. Guru mengarahkan siswa untuk melakukan Dan memahami dari apa yang sedang di jelaskan

e. Guru memberikan kesempatan kepada siswa untuk menunjukkan bahwa mereka bisa dengan mengerjakan soal

f. Guru mengarahkan siswa untuk memberikan contoh dan bukan contoh dari materi. (generalisasi)

g. Guru memberikan LKS dalam bentuk permainan

h. Guru membimbing siswa untuk menyelesaikan LKS.

i. Guru mengarahkan kepada siswa untuk selalu bekerjasama sesuai dengan kelompoknya

j. Guru memberikan penjelasan ulang terkait dengan beberapa siswa atau kelompok yang masing kurang mengerti.

k. Guru mengarahkan siswa untuk menyajikan hasil pekerjaan yang diwakili oleh beberapa siswa.

l. Kelompok lain diminta untuk menanggapi.

m. Guru melihat kelompok mana yang paling aktif dan semangat dalam menyelesaikan soal tersebut

\begin{tabular}{|c|c|c|c|}
\hline No & Aspek yang diamati & $\begin{array}{c}\text { Rata } \\
\text { - } \\
\text { Rata }\end{array}$ & Ket \\
\hline \multirow[t]{2}{*}{3} & $\begin{array}{ll}\text { Kegiatan Penutup: } \\
\text { a. } & \begin{array}{l}\text { Guru mengarahkan siswa } \\
\text { untuk membuat rangkuman } \\
\text { dan sintesis terhadap materi }\end{array} \\
\text { pembelajaran. } \\
\text { b. } & \text { Mengulangi inti dari materi } \\
& \text { Himpunan } \\
\text { c. } & \text { Guru memberikan tugas } \\
& \text { mandiri (PR) atau } \\
& \text { menyampaikan gambaran } \\
& \text { materi untuk pertemuan } \\
& \text { selanjutnya. }\end{array}$ & $\begin{array}{l}3,33 \\
4,00\end{array}$ & $\begin{array}{l}\text { Baik } \\
\text { Sanga } \\
\text { t Baik }\end{array}$ \\
\hline & Nilai Rata-rata & 3,44 & Baik \\
\hline
\end{tabular}

Berdasarkan hasil analisis pada tabel di atas menunjukkan bahwa rata-rata di setiap aspek kemampuan guru dalam mengelola pembelajaran Himpunan dengan pendekatan realistik dan saintifik berada pada kategori baik dan sangat baik.

\section{2) Analisis keefektifan perangkat pembelajaran}

Pada bagian sebelumnya, telah dikemukakan hasil uji kevalidan perangkat pembelajaran dan instrumen yang lain. Selanjutnya akan dideskripsikan hasil uji keefektifan. Pada bat asan istilah telah dinyatakan bahwa perangkat pembelajaran efektif apabila memenuhi 3 dari 4 kriteria tetapi kriteria ketuntasan belajar secara klasikal harus tercapai, kriteria tersebut adalah (1) aktivitas siswa, (2) respons siswa terhadap perangkat pembelajaran, dan (3) ketuntasan hasil belajar.

\section{3) Hasil respon terhadap kegiatan pembelajaran.}

Untuk angket respon siswa, berdasarkan hasil uji coba diperoleh hasil respon siswa terhadap kegiatan pembelajaran, buku siswa, LKS, dan Guru lebih dari 70\% siswa merespon positif untuk setiap item masing-masing aspek. Dengan demikian menurut kriteria yang ditentukan pada BAB III bahwa minimal 70\% siswa merepon positif dari $75 \%$ item yang diajukan untuk setiap aspek maka dapat dikatakan bahwa respon siswa "positif" terhadap perangkat pembelajaran.

\section{4) Hasil Tes Belajar}

Hasil analisis deskriptif perolehan nilai hasil belajar siswa setelah pembelajaran dengan menggunakan pembelajaran Himpunan dengan kombinasi pendekatan realistik dan saintifik dapat dilihat pada tabel berikut:

TABEL 4

STATISTIK PEROLEHAN HASIL BELAJAR SISWA

KELAS VII SMP N 21 MATARAM

Statistik Deskriptif

Ukuran subjek

Nilai

29 


\begin{tabular}{ll}
\hline Nilai terendah & 40 \\
\hline Nilai tertinggi & 100 \\
\hline Nilai rata-rata & 83,10 \\
\hline Jumlah Siswa Yang tuntas & 27 \\
\hline $\begin{array}{l}\text { Jumlah siswa yang Tidak } \\
\text { tuntas }\end{array}$ & 2 \\
\hline
\end{tabular}

Tabel 4 di atas menunjukkan bahwa hasil belajar himpunan siswa kelas VII SMP N 21 Mataram memiliki nilai rata-rata 83,10. Nilai minimumyangdiperoleh siswa adalah 40 dan skor maksimum yang diperoleh siswa adalah 100.Jika skor hasil belajar dikelompokkan dalam lima kategori, maka diperoleh tabel distribusi frekuensi berikut:

TABEL 5

DISTRIBUSI FREKUENSI DAN PERSENTASE SKOR HASIL BELAJAR HIMPUNAN

\begin{tabular}{|c|c|c|c|}
\hline Nilai & Kategori & Frekuensi & $\begin{array}{c}\text { Persentas } \\
\text { e (\%) }\end{array}$ \\
\hline $0-54$ & Sangat Rendah & - & 0 \\
\hline $54-64$ & Rendah & 2 & 6,8 \\
\hline $55-64$ & Sedang & 5 & 17,2 \\
\hline $65-84$ & Tinggi & 12 & 41,3 \\
\hline $85-100$ & Sangat Tinggi & 10 & 34,4 \\
\hline & umlah & 29 & 100 \\
\hline
\end{tabular}

Tabel 5 di atas menunjukkan bahwa dari 29 siswa yang mengikuti tes hasil belajar terdapat $6,8 \%$ siswa berada pada kategori rendah, $17,2 \%$ siswa beradapada kategori sedang, 41,3 \% beradapada kategori tinggi, dan 34,4\% siswa beradapada kategori sangat tinggi. Hal ini menunjukkan bahwa pemahaman siswa tentang materi yang disajikan dengan menggunakan perangkat pembelajaran dengan menggunakan kombinasi pendekatan realistik dan saintifik cenderung bervariasi.

\section{Deskripsi Hasil Penyebaran}

Perangkat yang dihasilkan pada tahap akhir pengembangan, selanjutnya disebarkan atau disosialisaikan secara terbatas pada beberapa guru matematika di SMPN 21 Mataram. Dari hasil penyebaran diperoleh beberapa saran yang digunakan untuk merevisi draft awal menjadi draft final sebagai pengembangan akhir perangkat. Saransaran dari peserta sosialisasi antara lain:

a. Masalah-masalah kontekstual yang disajikan pada buku siswa dan lembar kegiatan siswa hendaknya memperhatikan tingkat perkembangan kognitif siswa dan disesuaikan dengan lingkungan sekitar siswa.

b. Masalah-masalah yang ada dalam buku siswa tersebut masih terasa susah bagi siswa untuk memecahkan masalah tersebut.

c. Pembelajaran himpunan dengan menggunakan kombinasi pendekatan realistik dan saintifik bagi siswa sangat bagus untuk diterapkan karena siswa sangat antusias dan termotivasi ketika proses pembelajaran dan siswa merasa nyaman dalam belajar. Untuk itu dalam pembelajaran himpunan dengan menggunakan kombinasi pendekatan realistik dan saintifik di harapakan dapat memberikan banyakcontoh dalam bahan ajarnya serta dalam lembar kegiatan siswa.

\section{Pembahasan Hasil Penelitian}

Pada bagian ini dikemukakan pembahasan hasil penelitian yang meliputi tiga hal, yaitu: ketercapaian tujuan penelitian, (2) temuan khusus, dan (3) kendala-kendala yang ditemui.

Ketercapaian tujuan penelitian yang akan diuraikan adalah seberapa jauh tujuan penelitian yang sudah direncanakan tercapai. Ketercapaian ini dikaitkan dengan kevalidan, kepraktisan, dan keefektifan perangkat pembelajaran himpunan dengan menggunakan kombinasi pendekatan realistik dan saintifik. Temuan khusus yang dimaksud dalam bab ini adalah temuan-temuan yang diperoleh selama pelaksanaan uji coba perangkat pembelajaran, khususnya yang terkait langsung dengan kondisi siswa yang menjadi subjek penelitian.Kendala-kendala dalam penelitian yang akan dikemukakan, yaitu kendala-kendala selama proses pengembangan perangkat, menyangkut tentang implementasi perangkat pembelajaran di kelas dan kesiapan-kesiapan yang diperlukan untuk memperoleh perangkat pembelajaran.

\section{a. Ketercapaian Tujuan Penelitian}

\section{1) Kevalidan}

Mengenai uji kevalidan dan berdasarkan hasil validasi dari para ahli maka dapat disimpulkan bahwa prototipe/draft (Buku Siswa, LKS, RPP dan THB) secara keseluruhan telah memenuhi kriteria kevalidan..

2) Kepraktisan

Berdasarkan hasil penilaian ahli dan praktisi dalam bidang pendidikan matematika terhadap perangkat pembelajaran dengan menggunakan kombinasi pendekatan realistik dan saintifik menyatakan bahwa perangkat pembelajaran tersebut layak untuk di gunakan dalam pembelajaran. Sedangkan berdasarkan hasil pengamatan terhadap perangkat pembelajaran oleh observer menyatakan bahwa perangkat pembelajaran terlaksana dengan baik pada saat uji coba.Berdasarkan hasil penilaian pengamat, maka perangkat pembelajaran telah memenuhi kriteria kepraktisan.

3) Keefektifan

Pada Bab III telah dikemukakan kriteria keefektifan perangkat pembelajaran yang meliputi: (1) Tes hasil belajar, (3) aktivitas siswa, dan (4) respons siswa. 
Kriteria yang harus dipenuhi sehingga suatu perangkat pembelajaran dikatakan efektif .

\section{Kendala-kendala yang dialami selama penelitian}

Dalam pelaksanaan penelitian ditemukan beberapa kendala yang dialami selama kegiatan pengembangan, baik sebelum maupun dalam kegiatan uji coba perangkat pembelajaran dengan pendekatan realistik. Kendala-kendala yang dimaksud dikemukakan sebagai berikut:

a. Pada awal ujicoba siswa masih terkadang sulit untuk mengubah kebiasaan belajarnya. Walaupun sudah di jelaskan sebelumnya bentuk pembelajaran himpunan dengan menggunakan kombinasi pendekatan realistik dan saintifik.

b. Pada pembentukkan kelompok terkadang siswa harus satu kelompok dengan teman akrabnya walaupun pembentukan kelompoknya sudah di buatkan dalam bentuk permainan.

c. Masih terlihat beberapa siswa yang kurang antusias dalam proses pembelajaran, sehingga solusinya disetiap kelompok di berikan beberapa poin demi lancarnya proses pembelajaran.

d. Butuh kerja keras karna siswanya kebanyakan yang kinestetik sehingga dan mereka cepat bosan jika belajarnya monoton.

\section{SIMPULAN DAN SARAN}

Penelitian ini bertujuan untuk menghasilkan perangkat pembelajaran matematika dengan kombinasi pendekatan realistik dan saintifik yang valid, praktis, dan efektif. Berdasarkan tujuan tersebut dan hasil penelitian yang telah diuraikan, maka pada bab ini dikemukakan kesimpulan dan saran sebagai berikut.

\section{Kesimpulan}

Berdasarkan hasil penelitian yang telah diuraikan pada Bab IV, maka dapat disimpulkan sebagai berikut:

a. Penelitian yang dilakukan adalah penelitian pengembangan perangkat pembelajaran himpunan dengan kombinasi pendekatan realistik dan saintifik yang terdiri dari empat tahap yaitu: (1) tahap pendefinisian (define), (2) tahap perancangan (design), (3) tahap pengembangan (develop), dan (4) tahap penyebaran (disseminate).

b. Perangkat yang dihasilkan pada penelitian ini meliputi: (1) Rencana Pelaksanaan Pembelajaran (RPP), (2) Buku teks pelajaran, (3) Lembar Kegiatan Siswa, dan (4) Tes Hasil Belajar. Hasil validasi dan analisis data uji coba menunjukkan bahwa perangkat pembelajaran matematika dengan materi pokok himpunan dengan kombinasi pendekatan realistik dan saintifik memenuhi kriteria kevalidan, kepraktisan, dan keefektifan.

\section{Saran}

Berdasarkan hasil penelitian ini, dikemukakan beberapa saran sebagai berikut:

a. Pengembangan perangkat pembelajaran dengan kombinasi pendekatan realistik dan saintifik hendaknya dikembangkan untuk materi lainnya agar dapat membuat siswa lebih tertarik, senang, dan aktif dalam belajar matematika.

b. Pengembangan perangkat pembelajaran dengan kombinasi pendekatan realistik dan saintifik hendaknya di sosialisasikan untuk beberapa sekolah-sekolah lainnya.

\section{REFERENSI}

[1] Isjoni. (2011). Cooperative Learning Efektifitas Pembelajaran Kelompok. Bandung: Alfabet

[2] Gravemeijer, K. (1994). Developing Realistic Mathematics Education. Utrecht: Freudenthal Institute

[3] Khabibah. (2006). Pengembangan Model Pembelajaran Matematika Dengan Soal Terbuka Untuk Meningkatkan kreativitas Siswa Sekolah Dasar. Disertasi tidak diterbitkan. Surabaya: PPs UNESA

[4] Kementrian Pendidikan dan Kebudayaan. (2013). Materi Pelatihan Guru Implementasi Kurikulum 2013. Badan Pengembangan Sumber Daya ManusiaPendidikan dan Kebudayaan dan Penjaminan Mutu Pendidikan

[5] Marpaung, Y. 2001. Prospek RME untuk Pembelajaran Matematika di Indonesia. Makalah disajikan pada Seminar Nasional Realistic Mathematic Education di FMIPA Universitas Negeri Surabaya

[6] Nurdin. (2007). Model Pembelajaran Matematika yang Menumbuhkan Kemampuan Metakognitif untuk Menguasai Bahan Ajar. Disertasi tidak diterbitkan. Surabaya: PPs Universitas Negeri Surabaya.

[7] Ratumanan, T.G. (2004). Belajar dan Pembelajaran. Surabaya: UNESA University Press.

[8] Rusman. (2012). Model-model pembelajaran (Mengembangkan Profesionalisme Guru). Jakarta: Jajawali Press

[9] Sahid. (2009). Pengembangan Perangkat Pembelajaran Aritmetika Sosial Dengan Pendekatan Realistik Setting Kooperatif dikelas VII SMP. Tidak diterbitkan. Makassar:PPs UNM.

[10] Slavin, Robert. (2011). Psikologi Pendidikan(Teori dan Praktek). Jakarta: PT. Indeks

[11] Suherman, E. dkk. (2003). Strategi Pembelajaran Matematika Kontemporer. Bandung: JICA

[12] Suprijono, A. (2009). Cooperative Learning. Yogyakarta: Pustaka Belajar.

[13] Thiagarajan, S. Semmel, DS. Semmel, M. (1974). Instructional Development for Training Teachers of Exceptional Children. A Sourse Book. Blomington: Central for Innovation on Teaching The Handicapped.

[14] Trianto. (2007). Model-model Pembelajaran Inovatif Berorientasi Konstruktivistik, Jakarta: Prestasi Pustaka Publisher.

[15] Trianto. (2009). Mendesain Model Pembelajaran Inovatif-Progresif. Jakarta: Prenada Media Group. 